\title{
„Dantė dar nenumirè ir gali tęsti savo darbą neangažuodamas fantazijos“ - Petro Klimo laiškai iš sovietinių lagerių
}

\author{
VILMA BUKAITE்* \\ Vilniaus universitetas, Universiteto g. 7, LT-01513 Vilnius \\ El. paštas: vilma.bukaite@gmail.com
}

\begin{abstract}
Diplomatas ir istorikas Petras Klimas (1891-1969) buvo vienas iš dviejų 1918 m. Vasario 16-osios Lietuvos Nepriklausomybès akto signatarų, ištverusių sovietines represijas ir grịžusių i Lietuvą. Už pagalbą Tadui Petkevičiui ir jo bendraminčiams, rengusiems vadinamąj inteligentų memorandumą Didžiosios Britanijos ir JAV vyriausybėms, ir ypač už valstybininko diplomatinę veiklą $1946 \mathrm{~m}$. kovo $30 \mathrm{~d}$. Ypatingojo pasitarimo buvo nuteistas dešimčiai metų pataisos darbų lagerio ir penkeriems metams tremties. Straipsnyje skelbiame kalinimo laikotarpiu P. Klimo rašytus laiškus svainei Barborai Lesauskienei, kuri priglaudè Prancūzijoje suimtą ir ¡̇ Lietuvą prievarta atgabentą sesers vyrą hitlerinès okupacijos metais. Ji rèmę giminaitł sovietinių represijų laikotarpiu ir šioms pasibaigus. Iki mirties P. Klimas gyveno B. Lesauskienès namuose. 1946 m. lapkričio 3 d. - 1949 m. kovo 16 d. rašyti glausti, santūrūs, dažniausiai dalykiniai laiškai yra saugomi Lietuvos nacionalinès M. Mažvydo bibliotekos Retų knygų ir rankraščių skyriuje (F130-1922). Jie ne tik svarbūs iškilaus valstybininko biografijos tyrinejjimams, bet ir yra lagerio kasdienybės, kalinių buities, jų laikysenos sunkių psichologinių traumų aplinkybėmis tyrinèjimų šaltinis.
\end{abstract}

Raktažodžiai: Klimas, Lesauskienė, Čeliabinskas, laiškai, lageris

\begin{abstract}
IVADAS
1918 m. Vasario 16-osios Lietuvos Nepriklausomybės akto signataras, diplomatas ir istorikas Petras Klimas per beveik septyniasdešimt aštuonerius gyvenimo metus net keturis kartus patyre politines represijas Lietuvoje esant visoms „svetimoms santvarkoms“. Dar mokantis gimnazijoje jam kartu su bendraminčiais buvo iškelta byla dèl laikraštèlio „Mokinių draugas" leidimo. Pirmojo pasaulinio karo metais dèl ịtarimų prisidejus prie Geisteriškių kaimo (dab. Vilkaviškio r.) gyventojų ginkluoto pasipriešinimo okupacinei vokiečių valdžiai jis tris mėnesius buvo tardomas Kalvarijų, vèliau - Vilkaviškio kalèjimuose. Antrojo pasaulinio karo metais, 1943 m. rugsèjo 18 d., hitlerinès Vokietijos pareigūnai lietuvių diplomatą suèmè jo namuose, Grasse, Prancūzijoje. Be jokių kaltinimų kalèjęs aštuoniolikoje Prancūzijos,
\end{abstract}

\footnotetext{
* Autore yra Valstybès Nepriklausomybès stipendijos laureatė
} 
Vokietijos, Belgijos, Lenkijos kalëjimų, tik 1944 m. kovo viduryje P. Klimas pasiekè Lietuvą ir Kaune pagaliau buvo paleistas. Sovietinei kariuomenei artinantis jis nesutiko pasitraukti i Vokietiją, kurioje neseniai patyrè represijas.

Diplomatas neišvengė ir stalininès teisèsaugos absurdo. Formaliu pretekstu areštuoti P. Klimą tapo jo pagalba memorandumą JAV ir Didžiosios Britanijos vyriausybėms rengusiems Lietuvos inteligentams. Lietuvos pasiuntinybei Paryžiuje ilgai vadovavęs diplomatas 1945 m. rugpjūtị išvertė Tado Petkevičiaus kartu su Petronèle Lastiene, Bronislava Pajẻdaite, Jonu Česnavičiumi ir Jadvyga Jablonskiene parengtą dokumentą i prancūzų kalbą. 1945 m. rugsėjo 19 d. Obelynejje (Ringaudų apyl., Kauno r.) Antano Koriznos pavarde gyvenęs ir ùkio darbus dirbęs P. Klimas buvo suimtas. Akivaizdu, kad, formuojant bylą, politinè veikla atkuriant valstybingumą nepriklausomoje Lietuvos Respublikoje ir priešinantis sovietinei okupacijai laikyta pagrindine nusikalstama veika. $1946 \mathrm{~m}$. kovo $30 \mathrm{~d}$. Ypatingojo pasitarimo sprendimu jam buvo paskirta dešimties metų pataisos darbų lagerio ir penkerių metų tremties bausmè, vadinamasis „detskij srok“ [1].

1946 m. balandžio 21 d., pirmąją Velykų dieną, iš Vilniaus geležinkelio stoties jis drauge su kitais Lukiškių kalejjimo politiniais kaliniais buvo išvežtas į SSRS gilumą. Gegužès pirmosios išvakarèse dalis ešelono, kurioje liko P. Klimas, buvo palikta Čeliabinsko (RSFSR) geležinkelio stotyje. Čeliabinsko I lageryje du pirmus mènesius pradirbęs statybose, o liepą ir rugpjūti - karo trofejjus iš traukinių iškrovusioje brigadoje, vèliau buvo grąžintas prie statybos darbų. 1947 m. pradžioje jis buvo perkeltas ị už dvidešimties kilometrų nuo Čeliabinsko esančią angliakasių gyvenvietę Kopejską. P. Klimas dirbo statybos brigadoje, vèliau jam patikèti dailidès ir staliaus darbai, kurị laiką dirbo lagerio buhalterijoje. Kalejime patirtas šaltis, stresas, maisto ir poilsio stoka pakirto sveikatą: jis susirgo chronišku bronchitu, diabetu, mikro- ir makroangiopatija, gydytojai jam konstatavo širdies ydą, regèjimą silpnino akių tinklainès pakitimai ir katarakta. Didžiąją bausmès dalị atlikęs P. Klimas $1954 \mathrm{~m}$. gruodžio 24 d. dèl invalidumo buvo paleistas ị laisvę [2] ir grị̌zo ¡̇ Lietuvą. Kaune, žmonos sesers Barboros Lesauskienès šeimoje, jis gyveno iki pat mirties 1969 m. sausio $16 \mathrm{~d}$.

Nedaug tèra liudijimų apie P. Klimo patirtị sovietiniuose lageriuose. Grịžęs ị Lietuvą, jis venge artimiesiems pasakoti apie patirtas represijas. Galbūt smulkiau prisimindavo jas bendraudamas su panašią lemti patyrusiais artimiausiais bičiuliais, visų pirma su Aleksandru Stulginskiu ir Juozu Urbšiu [6] (1). Bene išsamiausiu ši jo gyvenimo laikotarpi atspindinčiu šaltiniu lieka iki 1949 m. kovo mėnesio kartu kalejjusio pedagogo ir vertèjo Antano Dambrausko prisiminimai [5]. Kitas labai svarbus šaltinis - trisdešimt du paties kalinio 1946 m. lapkričio 3 d. - 1949 m. kovo 16 d. rašyti laiškai dar vokiečių okupacijos metais Lietuvoje ji globojusiai svainei B. Lesauskienei, saugomi Lietuvos nacionalinės M. Mažvydo bibliotekos Retų knygų ir rankraščių skyriuje (F 130, b. 1922).

Viename iš laiškų tuomet ị Kauną grižusiam P. Klimui A. Dambrauskas pasakojo: „Buvau patekęs ị beveik absoliučią agrafiją. Labai retai tegalèjau parašyti pačiais elementariausiais gyvybiniais reikalais" [3]. Lyginant su kitu P. Klimo rašytiniu palikimu, jo laiškų iš tremties turinys verčia manyti apie panašią autoriaus būseną. Tačiau jų glaustumas ir turinio buitiškumas nesietinas vien su gynybine reakcija ị sunkias psichologines

(1) Traumų psichologijos specialistai, tyrinèję represuotųjų pasirinktus skaudžios patirties įveikos būdus, nurodè represijas patyrusių draugų paramos svarbą to paties likimo žmonèms. Lietuvoje atlikto tyrimo rezultatai rodo, kad tas pačias represijas patyrusiųjų draugų parama ypač svarbi politiniams kaliniams. 
traumas „odisėjos, kurios tikrovė prašoka Alighieri vaizdus“ [4] (2), metu. Asketišką jų turinị lèmė ir nedideli popieriaus lapeliai arba atvirlaiškiai, naudoti susirašinejjimui, ir būtinybè, jog laiškai pasiektų adresatą, ir svarba nurodyti svarbiausius poreikius bei padèkoti už gautuosius siuntinius. Iš represijų vietų siunčiami laiškai buvo labai griežtai cenzūruojami, kartais išbraukomos nepriimtinos vietos, o kartais ir visai sulaikomi. Todèl, kaip ir daugelis kalinių, dalies žmonių P. Klimas mini tik vardus, kai kur renkasi eufemizmus („Vytuko draugo Peteliuko mama“ - P. Klimo žmona), kartais naudoja abstrakčius apibendrinimus.

Be B. Lesauskienès, siuntinius P. Klimui siųsdavo dukteréčia Aldona Gulbinienè ir Ona Landsbergienè. Parengiant dalị siuntinių, netiesiogiai pagelbejjo paties P. Klimo ir išeivijoje gyvenusių buvusių jo kolegų bei bičiulių, ypač S. Lozoraičio, šeimos. P. Klimas ir A. Dambrauskas Čeliabinske bei Kopejske gaudavo ir Žiaužerès, Sesès slapyvardžiu pasirašytus pedagogès, muziejininkès Ievos Andriulytės laiškus [5, 66], knygų ir keletą periodinès spaudos leidinių.

P. Klimo laiškai svarbūs kaip sovietinių represijų tyrinejjimo šaltinis. Vyraujantis istorinių šaltinių žanras - politinių kalinių ir tremtinių atsiminimai - dažnai neatkuria smulkesnių represijų laikotarpio buities detalių, atspindi labiau apibendrintą praeities vaizdą, dažnai interpretuojamą ir savicenzūruojamą pagal šiandienos jausenas. Tad kalinių epistolinis palikimas yra vertingas kaip tuolaikinis represuotųjų aktualijas atspindintis šaltinis, ypač aktualus tiriant lagerio kalinių kasdienybę ir išgyvenimo taktiką. P. Klimo laiškai, koks santūrus bebūtų jų turinys, gana vaizdžiai atspindi sudètingą kalinių būtị visokeriopo stygiaus, maisto trūkumo ir šalčio bei grèsmių asmeniniam saugumui aplinkybėmis. Jie kvestionuoja ir mitą, kad kalintieji „nieko negalèjo papasakoti“ apie savo būklę: tiesmukų politinių pasisakymų juose nèra, bet represinès sistemos kritikos autorius nevengè: „Jeigu vèžio ligai neatsiras chirurgo?"

1946 m. lapkričio 3 d. - 1947 m. sausio 23 d. laiškai parašyti pieštuku ant A5 formato popieriaus lapo, sulankstyto trikampiu. Nuo 1947 m. rugpjūčio 31 d. P. Klimas rašè rašalu ant atvirlaiškių - tuomet jo laiškų tekstai dar sutrumpejo. Straipsnyje jie sunumeruoti pagal byloje naudotą tvarką, greičiausiai pagrịstą chronologiniu principu (nurodytas bylos lapo numeris, tik 1.15 yra vèlyvesnis nei 1. 16). Skelbiamas dvidešimt vienas laiškas - pasirinkti tie, kurių tekstuose yra daugiau detalių arba autoriaus samprotavimų. Jau pirmasis laiškas ir gerokai trumpesnès už kalëjimo laikotarpi išlikusio susirašinejjimo chronologinès ribos liudija, kad fonde prieinama tik dalis P. Klimo laiškų B. Lesauskienei. Kitų likimas nežinomas. Gana neịprastas yra poetinės retorikos ir išmonès kupinas laiškas Nr. 4 (Čeliabinskas, 19460101 ), parašytas tą pačią dieną kaip ir kitas, gerokai tipiškesnis, buitinio turinio laiškas Nr. 5. Matyt, kuriam nors laiškui nepasiekus adresato, 1948 m. pirmojoje pusėje dali jų P. Klimas rašè rusų kalba, kai kuriuos pakartodamas ir gimtąja kalba (publikuojant buvo pasirinktas lietuviškasis variantas). Laiškų siužetai gana panašūs, daugumą jų galima apibendrinti formule: kreipinys, įžanga apie naujausius ịvykius, gauti siuntiniai ir laiškai, lagerio buitis, savijauta, ịpareigojimai ir prašymai (kartais ịvardijami post scriptum dalyje), linkejjimai ir atsisveikinimas. Siekiant kuo tiksliau perteikti autoriaus retoriką, palikta autentiška laiškų rašyba ir skyryba, laužtiniuose skliaustuose įterpiant sutrumpintai šaltinyje užrašytą arba numanomą žodị, nurodant rankraščio puslapi bei pateikiant datas šiuolaikine rašyba. Dalis laiškuose minimų vardų liko neiššifruota.

(2) Dante Alighieri Dieviškojoje komedijoje vaizduojamo pragaro motyvą kaip tremties alegoriją jis kartojo skirtinguose epistolinio žanro tekstuose. 


\section{PETRO KLIMO LAIŠKAI}

\section{1. Čeliabinskas, 1946 m. lapkričio 3 d.}

Mieloji, 33 ir 34 atviruką gavau. Bet siuntinio su akiniais, apie kurị rašei, vis dar nesu gavęs. Matyti, kur nors užkliuvo. $O$ jo aš ypatingai laukiau, nes šio mènesio pabaigoj mums neišdavè visai arba [išdavè $-V$. B.] tik dalị duonos. Be to mane vèl iš invalidų išrašè ị darbininkus ir tris dienas pakasęs sušalusią kaip akmenį žemę gavau tokią arklišką slogą su temperatūra, kad turejjau atgulti ir kol kas drybsau barake. Rytoj turbūt jau varys vèl darban, nes temperatūra nukrito, nors aš dar svyruodamas bepavaikščioju ir iš manęs toks pat juodadarbis kaip iš kunigo šiaučius. Pasidaryti čia invalidu nenoromis gali, o ypačiai [esant] tokiems juodiems darbams, kuriems mus čia pristato nepaisydami visų mūsų mokslų ir profesijų. Kam tat yra darbas, o man tik kančia ir marinimas. Bet nieks nieko nežiūri.

Pasimatyk su Čereškiene [Obelynès ūkị valdžiusio Felikso Čereškos žmona - V. B.], pas kurią dar yra mano rudas kostiumas ir pamuštas kailiniais paltas (ne mano ir ne tavo, bet mano intencijai iš ten, kur liko juodas kostiumas su čemodanu). Ir bendrai pasikalbèk su ja apie jos pergyvenimus ir gal man ši bei tą galèsi pranešti, jei ji pati man nenorètų vieno kito žodelio parašyti apie bendrus mūsų pažistamus.

Bučiuoju abudu - dèdè Petras

[L. 1v] Čereškienès ūky (lapyne) tvarteliuose, kur kadai džiovėm tabaką ir pupas, vienoj skrynioj, kur aš kadais savo darbą dirbau, buvau palikęs kailinius - jei jų kas iš ten neišnešè, tai ir dabar gal guli. Jei įtaisèt naujus - jie nereikalingi, bet būtų gaila. Virtuvejj gi kampinèj lentynoj užkišau savo laikrodị (dèžutèj) - galètum ji parduoti: žinai, tą permatomąji - jis ir dèl to šio to yra vertas.

\section{2. Čeliabinskas, 1946 m. gruodžio 5 d.}

Mieloji, štai praejjo ir gruodžio $4 \mathrm{~d}$. Oras betgi nepasikeitè. Šiandien švenčiame Konstitucijos šventę neidami darban. Tai ir visa paguoda. Pakirtęs sušalusią žemę iki $60 \mathrm{~cm}$ moku džiaugtis poilsiu. Bet rytoj vèl tas pats. Šiandien mokejjo pinigus brigados kai kuriems dalyviams, bet man vèl neteko nei kapeikos. Vadinasi jau trečias mėnuo kaip nieko negaunu už perlaidas, kurias man pasiuntei. Negaunu nieko ir iš paimtų pinigų Kauno kalëjime (750 rub.). Priežasties aš nesugaudau ir nesuprantu. Jos man čia niekas nei paaiškinti nemoka. Siuntinio, pasiųsto lapkričio 20 d., aš dar negavau. Gi senuosius jau esu bebaigiąs. Dar tik lakšenų [lakštinių - V. B.] beturiu, kurios man sekasi virti, nes nereikalauja ilgos ugnies dèl kurios čia tenka sunkiai varžytis. Kameroj (sekcijoj) daug žmonių ir lietuviškas drovumo būdas pasirodo nepraktiškas. Šiaip esu sveikas ir šiaip taip išsiverčiu siuntiniais. Tik jau pritrūkau tų [1. 2v] gerų vilnonių siūlų, kurių jau buvai pasiuntusi priešpaskutiniame siuntiny. Kojinès darbe, mat, greitai kiūra... Šiandien esu gavęs Biliūno knygelę ir net ketvertą laikraščiu mažų banderolių (po 1 laikr.). Būtų patogiau man gauti atvirukų blankų. Parašyk, jei turi tikrų naujienų. Gandai mūs negali tenkinti. Kančia mus atpratino nuo vilčių.

Ar tikrai nèra jokių būdų pranešti mano adresą Vytuko [B. Lesauskienès sūnus Vytautas - V. B.] draugo Peteliuko [Petras Klimas jaunesnysis - V. B.] mamai? Gal ji galètų man kaip nors padèti? Ar neteko gauti laiško iš dèdès Povylo, jei jis jau žino, kur ir kaip aš esu? Labų dienų Žiaužerei ir ačiū už banderoles. 

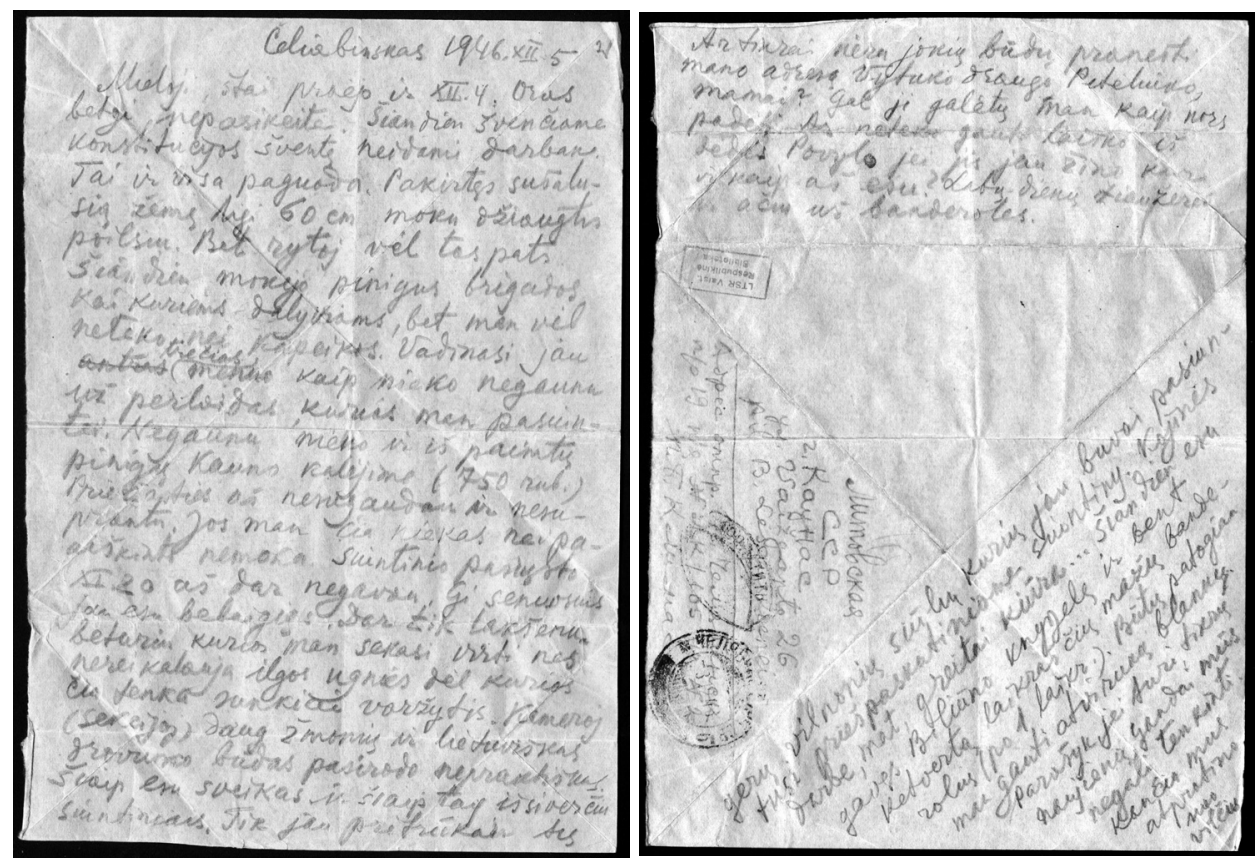

1 pav. 1946 m. gruodžio 5 d. Petro Klimo laiškas Bronei Lesauskienei, Čeliabinskas. Nacionalinès M. Mažvydo bibliotekos Rety knygų ir rankraščiu skyrius (toliau LNMMB), f. 130, b. 1922, I. 2, 2v.

\section{3. Čeliabinskas, 1946 m. gruodžio 8 d.}

Mieloji, užvakar gavau siuntinį su megstiniu, apykakle, kojinėmis, fliažka [buteliuku - V. B.] žuvies taukų, maišeliu cukraus, kelnèmis, lašinių gabalu, vigantoliu [vitaminu D - V. B.] ir tabaku. Už viską labai ačiū, nes jau tą dieną buvau užbaigęs savo atsargas. Megstinis labai šiltas ir patogus - jis reikalingas ypač dabar užejjus šalčiams. O kasant arba skaldant griovius, kaip akmenis, speige ir be mažiausio šilto viralo per ištisą dieną ir [su] trimis megstiniais dabar darosi nejauku. Šiaip nieko naujo. Nors vargą vargstame begalinị ir darbą dirbame nepakeliamą, bet aš vis dar stoviu ant kojų nepargriuvęs. Manęs nenori laikyti invalidu nepaisydami mano 56 metų ir neatsižvelgdami ị mano profesiją teikia patị juodąjį ir sunkiausią fizinị darbą. Iš tikrųjų, kas gali būti piktesnio, kaip su kyliais, kūjais, kirkomis, dalbomis skaldyti įšalusią žemę atžuliame šaltyje ir pašèlusiuose vejuose! Tik Tavo siuntiniai mane palaiko. Prisipirkti ko nors iš šalies dabar nebegaliu, nes pinigų man neišduoda, o ką turèjau, pabaigiau. Aš manau, kad ne pro šalị būtų pašte oficialiai (raštu) pasiteirauti ar siųstieji pinigai tikrai yra išsiųsti ị Čeliabinsko pataisomųjų darbų koloniją Nr. 1 ir ar yra pakvitavimas, kad visi tie pinigai tikrai čia gauti mano vardu. Aš čia apie tai negaliu sužinoti.

Bučiuoju abudu - dèdè Petras

\section{4. Čeliabinskas, 1947 m. sausio $1 \mathrm{~d}$.}

Geroji Fejja, nors Tamsta prabilai žemiška kalba, bet man Tamsta pasilikai savo fejiškos prigimties, kuri mums čia labiausiai brangi. Tamstos laiškai man buvo ir pasilieka didžiausia paguoda 
tame devintame rate, kuriam esu įmestas. Tamsta iš pat pradžiu įspejjai reikalą ir todèl aš kitaip negalëjau Tamstos traktuoti kaip kito pasaulio globejją. Vieno ko aš bijojau tai kad Tamsta mūsų neapleistum. Todèl ilgèliau negaudamas Tamstos laiško - aš jau nerimstu ir dienos darosi ilgesnès ir skurdžios. Su Antanu [Dambrausku - V. B.] mes tada rezgame visokiausių hipotezių. Bet Fẻja pasirodo ir mes džiaugiamès net galvą laužydami. Mes meldžiamès, kad Apvaizda išlaikytų Tamstą nežemiškuose ratuose, kurie dar neturejo Dantès.

„Pergalès“ Nr. 1 ir Nr. 3 gavau. Antanas gavo Korsaką. O laikraščių negaunu. Šiaip laikausi dar, šalčiai nėra dideli, o Jūsų pagalba dvasią ir kūną papeni kaip tik laiku. Ar pažįsti Tamsta Onutę, kuri man atsiuntè siuntinį?

Geriausių linkèjimų - Jūsų dèdè Petras [L. 4v] Ačiū už linkèjimus N[aujiesiems]. M[etams]., norečiau palinkèti ir Tamstai, bet Fejjos savo prigimtim nèra surištos nei su laiku, nei erdve. Mes čia maždaug taip pat.

\section{5. Čeliabinskas, 1947 m. sausio $1 \mathrm{~d}$.}

Mieloji, susilaukęs $\mathrm{N}$ [aujųjų] M[etų], manau vèl turèsiąs metų laikotarpị pasvajoti apie nerealius daiktus arba bent išklausyti kitų svajones. Tą dieną aš švenčiu neidamas darban, bet užtat dirbau ir per Kūčias ir per Kalèdas ir net sekamą sekmadieni. Oras tuo tarpu buvo švelnus - vos $10^{\circ}-15^{\circ}$. Tačiau darbas vis tas pats: sušalusių griovių kasimas, o vakar ir akmenų nešiojimas ị statomajji namą. Gavau atvirukus rašytus gruodžio $14 \mathrm{~d}$. ir gruodžio $20 \mathrm{~d}$.; paskutiniame rašai apie vailokus [veltinius - $V$. B.], kurių aš laukiu nes su batais čia per šalčius kojas prigelia nepaisant 4 porų kojinių ir dar autų. To siuntinio dar nesu gavęs. Abu su Antanu gailimès negalëję naujajame bute kartu kavos pagerti... Ar bepagersime?.. Jei vežio ligai neatsiras chirurgo? Tuo tarpu Tavo dẻka ir kitų tetų rūpesniu aš laikausi pusètinai, jei tik tas sausas kokliušiškas kosulys manęs nekamuotų. Kiti jaunesni brigados nariai vienas po kito nusivarè, nors fizinis darbas buvo jiems prigimtas.

Bučiuoju abu - dèdè Petras [L. 5v] „Pergalę“ Nr. 1 ir Nr. 3 gavau. Bet laikraščiai kažkur dingsta. Turbūt kas nors surūko. Jei jie buvo apdrausti, reikètų reklamuoti. İdomu, kaip pasiaiškins ta sistematiška avarija.

\section{6. Čeliabinskas, $1947 \mathrm{~m}$. sausio $10 \mathrm{~d}$.}

Mieloji, siuntinị su veltiniais ir kaliošais gavau tvarkoj, t. y. su visu atvirutejj paminètu turiniu. Labai ačiū. Veltiniai nors kiek mažoki, nes galiu ịsiauti tik su plonomis kojinemis, bet šiltumas jų stebuklingas. Darbe dabar visai nebešąlu kojų kaip pirma su batais. Rašei, kad tai dovana tetos Antosès - padèkok jai nuo manęs pasakydama, kad jais ji man išgelbèjo gyvybę kiek ji čia galejjo pareiti nuo kojų. Labai mane pradžiuginai kava ir cukrum: tai vienintelis man čia luxus. Parkerị kaip rašei vieną atidaviau, o kitą mėginsiu poilsio dieną pritaikinti laiškui, jei pavyks rasti indą rašalui pasidaryti. Šiaip pas mane jokių naujienų nèra. Darbas vis tas pats grioviuose ir nelengvejja. Bet dar laikausi, nors esu seniausias brigadoje. Laikraščiu jau kelios savaitės visai negaunu. Matyti kur nors pakeliui nueina dūmais. Ar vis neradai kokios progos susisiekti su Brone [Klimiene, P. Klimo žmona - V. B.]? Aplinkiniai keliai kartais esti trumpesni.

[L. 6v] Bučiuoju abu - Petras

Gavau laišką iš Čereškienès. Ji rašo pasiuntusi man 50 rub. Gal ji galètų pačiai padèti maistu - jei ne ji, tai jos viršininkè kaimynystejje [Honorata Ivanauskienè - V. B.]. Būt ne pro šali su ja susieiti. Mano daiktus iš ten paẻmusi Aldona [Gulbienienė, P. Klimo dukteréčia - V. B.]. Aldona telegrafavo serganti ir antrą siuntinį atsiųs kiti. 
7. Čeliabinskas, 1947 m. sausio $12 \mathrm{~d}$.

Mieloji, gavau atviruką, rašytą gruodžio 31 d. su sveikinimais. Ačiū, taip pat nuo Antano. Bijai ką tie N[aujieji]. M[etai]. atneš, arba dèl to kad nežinai. Mes čia tokios baimès nejaučiame nes mes niekad sapnų nesapnavome. Klausi ar atsiųst tuos kailinius kurie paliko pas Č[erešką]. Man jų nereikia - tie trumpi kailiniukai, kuriuos jau seniau buvai atsiuntusi man visai pakanka, ypač darbe jei patogūs. Aš jiems pats prisidèjau puikią apikaklę, kurią buvau radęs kaip šlavikas méšlyne išmestą. Aš ją išskalbiau, sulopiau, padejjau pamušalą ir dabar bet koks siuvejjas vargu mane sukonkuruotų tame darbe. Rašai dar kad siuntinị išsiuntei be riebalų, be cukraus. Bet aš gavau drauge su veltinais ir riebalų, ir cukraus... Jie buvo iš Vaižganto 26. Tiesa, daug jų nebuvo, bet mes čia džiaugiamès ir trupiniais. Skalbinių ir rūbų man tuo tarpu jokių nereikia ir jų nesiųsk. Laikausi tik maisto priedu ir tavo arba prietelių atnaša [bičiulių aukomis - V. B.]. Duok Dieve, Jums visiems už tai gyvenimą laimèti geriau už mane. Gavau Vienuolio „Užžèlusiu taku“, apie kurią X nieko nerašè. Kitos neateina. Dabar pas mus nešalta $-20^{\circ}$. Grįžo vẻl ị mano koloniją [Anelè - V. B.] Pladienè ir keletas lietuvaičių, bet mes nebegalime matytis, nebent bus kada progos susitikti darbe.

[L. 7v] Bučiuoju abu - dèdè Petras Čereškienė paraše laišką. Tą itališką knygą buvo paemusi Tau grąžinti josios drauge Bronė ar Petronèlè [Bronislava Pajedaité, Petronèlè Lastienè - V. B.]. Šiaip ten beveik nieko nèra likę, tik labai smagios šeimininko [Felikso Čereškos - V. B.] man darytos klumpaitès bet jos negi mano. Dar paliko rodos atliekamoj lapių būdoj mano akiniai.

8. Kopejskas, 1947 m. sausio 23 d.

Mieloji, atsidūriau kartu su Antanu naujoj kolonijoj. Teko tad būti etape kartu su galybe čionykščiu paprastų nusikaltèlių. Kelias dienas neteko nei miegoti, nei praustis - ir dabar neturiu kuo nusiprausti. Vakar ir šiandien mano senoji brigada, papildyta naujais žmonèmis, gyvename skyrium barake (str. 58) apie 40 žm. [onių]. Todẻl jau galiu ramiau miegoti. (Antanas jau trečia diena eina dirbti naktị, aš dirbu kolonijos zonoje: nešioju smiltis, cementą, lentas, etc.). Kad galètum tiksliai ịsivaizduoti mano padètị, pasakysiu tiksliai, ką aš beturiu. Bendrai esu kaip stoviu: dar turiu porą marškinių, porą ap[atinių]. kelnių, tris megztinius, žiponèlị [liemenę - V. B.], kailiniukus, vieną porą kojinių (plonų), vailokus (bet jau be kaliošų), vatines kelnes (čia Čeliabinske įsigytas), kepurę, šalikèlį, kailines pirštines, vieną vilnonę baltą pirštinę, maišą, maišelị (tuščią), piniginę (tuščią), pieštuką ir Antano vytą virvę... Valgyti čia duoda 650 gr. duonos (kartais 350 gr.), samtelį sriubos rytą, kelis šaukštus košès rytą ir tiek pat vakare (teduoda du kartu ir viskas). Dirbti reikia visą dieną nuo 7-8 val. ligi 5 vak[aro]. Gerai, jei gaunam valandytę pasišildyti. Jūsų meilès atnašos išgaravo su guzais ant nosies, žandų, etc. Jautėmès ir dar jaučiamės kaip Koliziejaus arenoje. Linksma. Tai jau antrą kartą: etape $1946 \mathrm{~m}$. per Velykas ligi gegužès mèn. ir dabar. Tik viena Apvaizda mus dar saugojo, bet jau pastirusius ir [1. 8v] subliuškusius ir kūne, ir dvasioje. Antanas kiek apkimęs, man nugaroj ir šone sopa nuo sunkenybių nešiojimo. Bet dar laikomės. Laišku ar siuntinių, kurie galèjo ateiti senu adresu, dar čionai neperdavè. Siuntinių tiesiog bijome, nes jie gali būti gyvybès kainos, jei nepasikeis apystovos [aplinkybès - V. B.]. Nežinome, ar išsaugosime savo kelnes. Nèra kas nei gina, nei apgina. Esame „taisomi“ tarp nepataisomų. Dantè dar nenumirè ir gali tęsti savo darbą neangažuodamas fantazijos. 


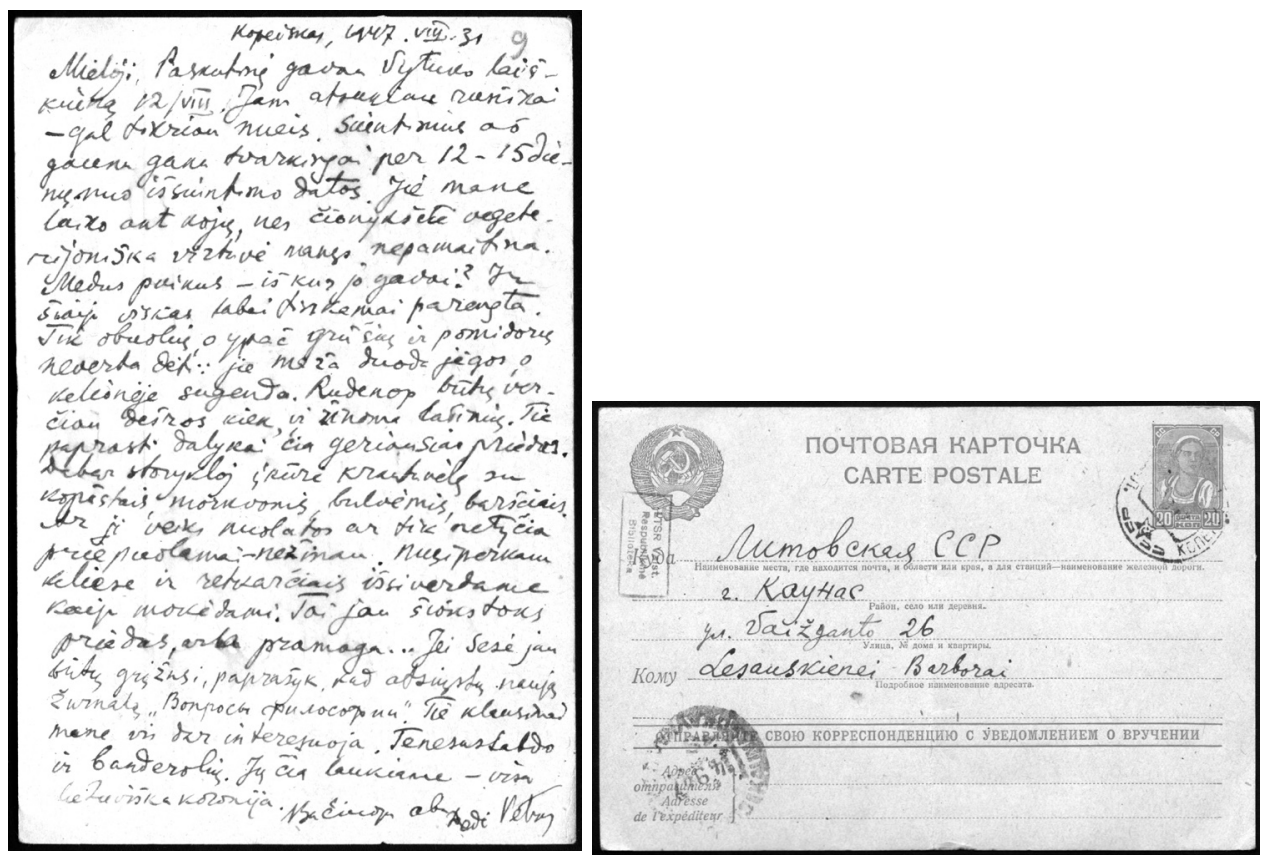

2 pav. 1947 m. rugpjūčio 31 d. Petro Klimo laiškas Bronei Lesauskienei, Kopejskas. LNMMB, f. 130, b. 1922, I. 9, 9v.

\section{Kopejskas, 1947 m. rugpjūčio $31 \mathrm{~d}$.}

Mieloji, paskutinị gavau Vytuko laiškiuką rugpjūčio 12 d., jam atsakiau rusiškai - gal tikriau nueis. Siuntinius aš gaunu gana tvarkingai per 12-15 dienų nuo išsiuntimo datos. Jie mane laiko ant kojų, nes čionykšte vegetarijoniška virtuvė manęs nepamaitina. Medus puikus - iš kur jo gavai? Ir šiaip viskas labai tinkamai parengta. Tik obuolių, o ypač grūšiu [kriaušių - V. B.] ir pomidorų neverta dèti: jie maža duoda jègos, o kelionejje sugenda. Rudeniop būtų verčiau dešros kiek, ir žinoma lašinių. Tie paprasti dalykai čia geriausias priedas. Dabar stovykloj ịkūrẻ krautuvèlę su kopūstais, morkomis, bulvėmis, barščiais. Ar ji veiks nuolatos, ar tik netyčia pripuolamai - nežinau. Nusiperkam keliese ir retkarčiais išsiverdame kaip mokèdami. Tai jau šioks toks priedas, arba pramoga... Jei Sesẻ jau būtų grịžusi, paprašyk, kad atsiųstų naują žurnalą „Вопросы философии“. Tie klausimai mane vis dar interesuoja. Tenesustabdo ir banderolių. Jų čia laukiame - visa lietuviška kolonija.

Bučiuoju abu - dèdè Petras

\section{1. Копейск, 7 сентября 1947 г.}

Милая, открытку от 30 августа получил вчера вместе с посылкой с тремя яблоками. Все пришло в полном порядке и справности. Спрашиваешь, что мне особенно нужно. Этого я не могу определить - по крайней мере все, что присылала мне до сих пор, всегда было хорошо. Разнообразие тоже замечательно. Из одежды мне пока ничего не нужно. Сапоги и валенки надеюсь получить, теплую нижнюю одежду на зиму пока каким-то 
счастьем сохранил, даже финскую шапку. Относительно лекарств - не беспокойся. Пока в них не нуждаюсь. Витамины конечно очень кстати; я их систематически употребляю и моя цынга уже значительно отошла. В общем я чувствую себя не плохо, как это возможно в заключении.

Целую обоих, не забывайте - Ваш дядя Petras

Vertimas: Kopejskas, 1947 m. rugsẻjo 7 d. Mieloji, rugpjūčio 30 d. atviruką vakar gavau kartu su siuntiniu su trimis obuoliais. Viskas buvo tvarkinga ir nepažeista. Klausi, ko ypač reikia. To negaliu nustatyti - visi ligšioliniai siuntiniai visada būdavo geri. I̦vairovè irgi vykusi. Iš drabužių man kol kas nieko nereikia. Batus ir veltinius tikiuosi gauti, šiltus žieminius drabužius kažkaip stebuklingai išsaugojau, net suomišką kepurę. Dèl vaistų nesijaudink. Kol kas man jų nereikia. Vitaminai, žinoma, labai praverčia, aš juos sistemingai geriu ir savo skorbutą jau gerokai apsigydžiau. Apskritai jaučiuosi neblogai, kiek tai įmanoma kalint. Bučiuoju abu, nepamirškit [manęs]. Jūsų dèdè <...>.

\section{Kopejskas, $1948 \mathrm{~m}$. sausio $1 \mathrm{~d}$.}

Mieloji, siunčiu Tau N. Metų linkèjimų. Sesès telegramą esu gavęs. Gavau tvarkoj taip pat siuntinị su pyragaičiais ir kt. Žinoma, senieji pinigai prapuolè. Už $10 \mathrm{r}$. tegavau $1 \mathrm{r}$. ir už visus likusius perlaidų pinigus. Kaip bus toliau - dar nežinoma. Šiaip pas mane nieko naujo. Žiemos dabar kaip nèra: sniegas tirpsta nuo stogų kaip pavasari. Todẻl kojos dabar šlapios veltiniuose - kas aršiau už šaltị. Kosulys užtat mane dabar pjauna be paliovos. Darbas žiemą ir tokioj darganoj biaurus: medžiai, lentos ir pats kirvis slysta iš rankų. Ką beatneš tie nauji metai - niekas turbūt ispèti negali.

Sveikinu visus, bučiuoju - dèdè Petras

16. Kopejskas, 1948 m. sausio 22 d.

Mieloji, siuntinị su puikiu pyragu gavau tvarkoj, 25 rub. taip pat šį kartą atidave, bet cenzorius liepe parašyti, kad pinigus ateity siųstum paštu. Matyti, toks potvarkis po pinigų reformos. Pas mane nieko naujo. Šiuo metu dar šiaip taip laikausi, bet žinoma darbas sunkiai išvargina. Mūsų brigada yra statytojų ir be to „pirmūnų“ rekordininkų, todèl daug dirbame. Jaunam žmogui dar visa tat pakeliama, o man jau nelengva. Gavau kiek pavelintai iš Sesès laišką, rašytą sausio $1 \mathrm{~d}$. Už visas jos žinias labai dèkoju. Tik atmintis mano taip nusilpnejo, kad niekaip neatsimenu tos Birutès, nei tos giminaites Liūdos nuo Mažeikių. Gal kaip nors man primins. Knygas (S. Nėries, Horatių) ir laikraščius gavau. Tik pasigedau kelių numerių apie Hitlerio galą.

Sveikinu visus, bučiuoju abu - dèdė Petras

15. Kopejskas, $1948 \mathrm{~m}$. vasario $1 \mathrm{~d}$.

Mieloji, siuntinị su žuvų taukais ir skardine taukų etc. gavau tvarkoj. Taip pat 25 r. dar šį kartą išdavè, nors vèl įspèjo siųsti perlaidomis. Šiaip nieko naujo. Šalčiai vèl padidèjo. Sveikata be permainų. Tik pavargstu nuo to dailidès ar statytojo darbo. Visą dieną tašydamas rankas atkalu. Kosulys mane taip pat smarkiai privargina. Gavau taip pat Sesès laišką. Liūdnas jis man buvo Eglès [Klimaitės-Fourier-Ruelle, P. Klimo dukros - V. B.] laiško priminimais. Kur ji ir 
kiti maniškiai? Vienas Dievas težino. Nejaugi joks ženklas negali parskristi? Kodèl man vis nieko apie Prano [Lesauskio, B. Lesauskienès vyro - V. B.] likimą neparašei, nejaugi neturi jokių žinių?

Bučiuoju abu - Jūsų dèdè Petras

19. Копейск, 8 марта 1948 г.

Милая, посылку с конфетами в россыпную и пр. получил в полном порядке, но по дороге в барак на меня напали так наз[ываемые]. блатные, или просто воришки и разорвав мешок (он был достаточно прочен) многое мне растаскали. Вырвали из рук также все газеты и журналы, которые я в такое время получил от цензора. У нас в коридоре барака теперь нет электричества и потому воры пользуются темнотой для своих делишек. У меня конечно уже нет столько сил, чтобы бороться с такой сворой.

Целую обоих - дядя Petras

Vertimas: Kopejskas, $1948 \mathrm{~m}$. kovo 8 d. Mieloji, siuntini su sveriamais saldainiais ir kt. gavau nepažeistą, bet pakeliui ị baraką mane užpuolè vadinamieji „blatnieji“, arba tiesiog vagišiai, ir, išplèšę maišelị (jis buvo pakankamai tvirtas), didžiąją dalị išgraibstė. Iš rankų išplěšè ir visus laikraščius bei žurnalus, kuriuos tada buvau gavęs iš cenzoriaus. Mūsų barako koridoriuje dabar nèra elektros, todèl vagys tamsoje imasi savo darbelių. Žinoma, aš jau nebeturiu tiek jègų, kad kovočiau su tokia gauja. Bučiuoju abu - dèdè $<\ldots>$.

\section{0. Копейск, 21 марта 1948 г.}

Милая, посылку, которую ты назвала пасхальной, я получил в полном порядке. На сей раз избег налета блатных и полностью донес до хранилища. Кстати попросил двоих товарищей для охраны. Мое здоровье, как всегда, без перемен: только борода сильно поседела и я сам постарел. С каждым днем мне становится тяжелее на работах. Кроме того меня всю зиму замучил кашель. А в общем все страшно надоело. Существование застряло в таком ужасном тупике в этих астрономических далях, что я потерял уже и способность говорить и думать.

Целую обоих - дядя Petras

Vertimas: Kopejskas, 1948 m. kovo 21 d. Mieloji, siuntini, kurị Tu pavadinai velykiniu, gavau visiškai sveiką. Šịsyk išvengiau „blatnųjų“ puolimo ir sèkmingai parsinešiau ị saugojimo vietą. Beje, pasikviečiau ir du draugus apsaugai. Mano sveikata, kaip visada, nesikeičia: tik barzda smarkiai pražilo ir aš pasenau. Kasdien man vis sunkiau sekasi dirbti. Be to, kiaurą žiemą mane kankino kosulys. Ir viskas baisiai pabodo. Būtis ịstrigo tokiame baisiame akligatvyje, tokiose astronominèse tolybėse, kad aš jau praradau gebėjimą kalbèti ir galvoti. Bučiuoju abu - dèdè $<\ldots .$. .

22. Kopejskas, 1948 m. balandžio $22 \mathrm{~d}$.

Mieloji, siuntinị, apie kurị rašei atviruke balandžio 3 d., gavau be jokių nuotykių ir visiškoj tvarkoj. Taigi talismanas padejo ir namie pasilikęs. Šiaip pas mane nieko naujo. Tik dabar neinu darban, nes votys po pažastim verčia laikytis „stacionaro“, t. y., pusiau ligoninèj. Čia 
gaunu tik 600 gr. duonos, bet tris kartus dienoje duoda kopūstų sriubos ir keletą šaukštų košès. Pas mus taip pat pavasaris, nors saulè dar nešildo, o tik purvyno pridirba. Per tas dienas skaitau - visos kolonijos lietuvių gautas knygas perskaičiau. Kitokių čia nèra. Žinoma, išskaitau ir banderolių medžiagą. Be to visas tas ilsèjimasis būtų nepakenčiamai nuobodus. Gal Vytukas atsiųstų savo fotografiją - iš jos aš ne tik ji „vyrą" pamatyčiau, bet ir Pitą [Petras Klimas jaunesnysis - V. B.].

Bučiuoju abu - dèdè Petras

23. Kopejskas, 1948 m. balandžio 28 d.

Mieloji, šiandien švenčiame Velykas. Netikètu būdu tas sekmadienis išẻjo šventės diena, t. y., neiname ị darbą, nes visoj zonoj turejjo būti padaryta inventorizacija. Šiaip nieko naujo. Pavasaris darosi šlapias. Senieji batai, žinoma, susinešiojo, bet dabar gavau pusbačius iš valdžios. Jie lengvi - vasariniai, bet aš juos įmoviau ị kaliošus. Tikiuos, kad tuo būdu apsisaugosiu nuo drègmès. Pas mus jau irgi pradèjo kalbèti apie užskaitas už darbą., t. y., už virš $100 \%$ atlikto darbo skaitys daugiau dienų sèdèjimui. Suprantama, kad seniems žmonėms ir nebe tokiems stipriems tai mažai žada. Tik stiprūs jaunieji gali tikètis terminus susitrumpinti.

Bučiuoju abu - dèdè Petras

29. Kopejskas, $1948 \mathrm{~m}$. rugsèjo $12 \mathrm{~d}$.

Mieloji, laiškelị rugpjūčio 23 d. gavau keliom dienom vèliau už siuntinị. Buvau smarkiai susirūpinęs negaudamas. Šiandien turime neramią dieną, nes mus „komisuoja“ (renka) naujam etapui, gal ị labai tolimus rytus. Bet dar neaišku. Nieks taip nenuvargina, kaip tie etapai. Juoba kad juose žmogus visko nustoji. Kol kas aš vis dar laikausi, nors senatve kasdien reklamuoja savo teises. Dar kiek laiko, ir aš turbūt baigsiu savo „darbingụjų“ karjerą. Sic transit...

Banderolę su „Pravda“ ligi rugpjūčio 22 d. gavau. Tai gerajai Apolonijai parašyk pati nuo manęs ir padèkok kaip dera mano padèty. Rašyk dažniau - be galo nyku be žinutès.

Bučiuoju abu - dèdè Petras

31. Kopejskas, 1948 m. spalio 5 d.

Mieloji, abi atvirutes (spalio $11 \mathrm{~d}$. ir rugsèjo 25 d.) gavau beveik kartu. Šiandien atejjo ir siuntinys, išsiųstas rugsèjo 11 d. Gavau viską tvarkoj. Klausi apie daiktus žiemai. Tuo tarpu ką žadi pasiųsti - gerai, ypač bateliai. Šiaip man visko tenka gauti iš valdžios. Skalbinių todèl nereikia. Kojinès gi ir pirštinès labai pravers, užtat niekuo nesirūpink. Tuo tarpu tik dalị iš mūsų brigados išsivežè nežinia kur. Aš ir Antanas kol kas paliekame čionai. Pinigų galima siųsti. Bet tuo tarpu išsiverčiu tais, kurių gaunu ir kuriuos uždirbu. Taigi spirginančio reikalo nèra. Gavau šiandien ir banderolę. „Pravda“ gavau ligi rugsèjo 26 d. Sveikata mano - senoviška. Laikausi kaip galima laikytis tokiose sąlygose. Tik nerimas ima kad tokiai būsenai nèra galo ir nesuprantama kuriam galui tos kančios reikalingos. Antanas laikosi gerai - kaip sudiržèjęs kavalierius. 
32. Kopejskas, 1949 m. kovo 16 d.

Mieloji, mano iškeliavimas šị kartą neịvyko: mane atrado jau per seną. Todèl apžiūrèję pasiuntė atgal ị tą pačią koloniją. Taigi vèl tuo tarpu esu senoje vietoje. Šiandien gavau ir siuntinị, kurio karakteristika: 27 r. ir lietuviškas „Kazbekas“ + pyragaičiai, etc. Bet atviruko nei dèl šito, nei dèl ankstyvesnio lig šiol nesu gavęs. Šiaip nieko naujo. Vèl dirbu savo brigadoj. Žinių apie Antaną dar neturiu [Dambrauskas 1949 m. kovą perkeltas iš Kopejsko ị Spasko (Kazachstanas) lagerị - V. B.].

Bučiuoju abu - dèdè Petras

Gauta 20110207

Parengta 20110403

\section{Šaltiniai ir literatūra}

1. $1946 \mathrm{~m}$. kovo $30 \mathrm{~d}$. Tado Petkevičiaus, Petronèlès Lastienès ir Petro Klimo baudžiamosios bylos nuosprendis, Vilnius. Lietuvos ypatingasis archyvas, f. K-1, ap. 58, b. P15617, 1. 236. P. Klimas nuteistas pagal RSFSR Baudžiamojo kodekso 58 str. 2 ir 11 punktus (ginkluotas sukilimas ar įsiveržimas ị SSRS teritoriją arba ginkluotas valdžios užgrobimas, siekiant nuo SSRS atskirti jos teritorijos dali; dalyvavimas antivalstybinėje organizacijoje arba organizuota veikla, siekiant parengti arba įvykdyti 58 straipsnyje minimus nusikaltimus), žr.: Уголовный кодекс РСФСР. Москва: Юридическое издательство НКЮ союза ССР, 1943. С. 27, 30.

2. 1954 m. gruodžio 24 d. SSRS VRM Lagerių skyriaus pažyma apie Petro Klimo bausmès atlikimą. Vitos ir Vaivos Lesauskaičiu privatus archyvas.

3. 1955 m. sausio 18 d. Antano Dambrausko laiškas P. Klimui. Vitos ir Vaivos Lesauskaičiu privatus archyvas.

4. 1956 m. gegužès 5 d. Petro Klimo laiškas dukrai Eglei Fourier-Ruelle. Žr.: GERUTIS, Albertas. Petras Klimas: valstybininkas, diplomatas, istorikas, kankinys. Cleveland: Viltis, 1978. P. 279.

5. DAMBRAUSKAS, Antanas. Viskas praeina. Vilnius: Vaga, 1991.

6. GAILIENĖ, Danutė; KAZLAUSKAS, Evaldas. Po penkiasdešimties metų: sovietinių represijų Lietuvoje psichologiniai padariniai ir ịveikos būdai. Iš: Sunkių traumu psichologija: politinių represiju padariniai. Vilnius: lietuvos genocido ir rezistencijos tyrimo centras, 2004. P. 109, 117. 
VILMA BUKAITÉ

\section{"Dante is still not dead and can continue his creations without engaging his fantasy" - Petras Klimas' letters from Soviet lagers"}

Summary

Letters from Soviet concentration camps (Rus. "lager") constitute a valuable source of the daily life history of Soviet political prisoners. These letters enable a better understanding of the daily life of repressed people, as well as the then psychological condition and tactics of survival in lagers. In the Martynas Mažvydas National Library of Lithuania, letters of the Lithuanian statesman, career diplomat and historian Petras Klimas are kept; these letters had been written during Klimas' confinement at lagers of the Chelyabinsk area (RSFSR) and dated from November 1946 until March 1949. We publish 21 of the 32 letters to Klimas wife's sister Barbora Lesauskienè. The woman harboured Klimas during the 1944-1945 Soviet repressions and after them. Klimas, a former career diplomat, lived at Lesauskienës home to his last days.

The published letters of Klimas significantly differ from other pieces of numerous written legacy; these letters are concise, of a distinctly objective matter and a of scarce daily-life content. Some letters in 1948 were written in Russian. Names of some persons were coded in synonyms. The subjects of the letters are mostly the same, they may be colligated by the following formula: name, latest introductory news, lately received packages and letters, daily-life in the lager, self-condition, obligations and requests, regards, and a farewell. The content of the letters contradicts the myth that lager prisoners had no possibilities to elucidate their situation; however, the letters do not contain straight political statements; the criticism of the repressional system was being conveyed as follows: "One may unwillingly become invalid here", "We stand a toilsome misery and backbreaking work", "What if the cancer will not see its surgeon?". The content reveals not only the physical and psychical challenges of political prisoners, but also elucidates the author's personal efforts to retain human dignity, needs for information and intellectual work, the ways of adaptation to lager life. 